\title{
A jury of none: an essay on the last acceptable form of civic banishment
}

\author{
James Michael Binnall
}

Published online: 20 March 2010

(C) The Author(s) 2010. This article is published with open access at Springerlink.com

\begin{abstract}
Though many socio-legal scholars have criticized those measures that deny convicted felons the right to vote, few have challenged the statutes that withhold a convicted felon's opportunity to sit on a jury. A majority of US jurisdictions bar felons from jury service permanently, creating a class of citizens defined and punished by the criminal justice system but unable to impact its function. This essay considers the invisibility of felon jury exclusion, notes its unlikely supporters, and asserts that by preventing convicted felons from taking part in civic processes, authorities work against reentry initiatives.
\end{abstract}

Keywords Felon · Jury · Exclusion · Civic · Reentry

\section{Introduction}

Nine years ago, in his remarkably insightful novel Bowling Alone, Robert Putnam argued that the citizenry of the US is civically disengaged (Putnam 2000). Relaying harrowing statistics of our nation's level of apathy he warned, "like battlefield casualties dryly reported from someone else's distant war, these unadorned numbers scarcely convey the decimation of American community life they represent" (Putnam 2000:42, further noting that "[i]n round numbers, every single percentagepoint drop represents two million fewer Americans involved in some aspect of community life every year"). Pointing to a waning desire to be a part of the American social fabric, Putnam concluded that Americans have been dropping out in droves, not merely from political life, but from organized community life more generally (Putnam 2000:64).

\footnotetext{
J. M. Binnall ( $\bowtie)$

University of California at Irvine, Irvine, CA, USA

e-mail: jbinnall@uci.edu
} 
As a convicted felon and practicing attorney, I am unlike the Americans Putnam described in his work, as I am not inclined to voluntarily withdraw myself from public life. Instead, various record-based legal constructs force me into civic isolation. Allegedly designed to protect the populace by purifying certain democratic processes, the "collateral sanctions" (American Bar Association 2003:1) and "discretionary disqualifications" (American Bar Association 2003:1) that limit civic participation form a series of interwoven legal boundaries demarcating areas of American democratic life that are off-limits to those who deviate from recognized law (Travis 2002:19, arguing that collateral sanctions "create a permanent diminution in social status of convicted offenders, a distancing between 'us' and 'them'”). Moreover, such legal constructs exist in relative obscurity, apply categorically, and force those with a criminal record to watch democracy move forward without ever influencing its direction. The practice of felon jury exclusion is one such legal construct. Routinely ignored, the measures that keep felons from the jury are as insidious as those that prevent felons from casting a ballot, yet they are tolerated. In short, they are the last acceptable form of civic banishment.

In their 2006 work, Locked Out: Felon Disenfranchisement and American Democracy, Jeff Manza and Christopher Uggen artfully described how a national event, the 2000 presidential election, "reminded all of us very forcefully of the importance of the right to vote" (Manza and Uggen 2006:v). Meticulously chronicling the evolution of record-based voting restrictions and describing the population affected, Manza and Uggen created a public discourse about a form of civic banishment previously overlooked. Their work and a stirring national news event shook the very foundations on which our founding fathers erected a form of governance "of the people, by the people, and for the people" (Lincoln 1863), and what followed were concerted efforts to repeal the statutes many believed to have influenced our nation's future. Scholars and policymakers aligned to alter the discourse surrounding the appropriateness of excluding a large swath of our population from the voting booth, and those with criminal convictions, trying desperately to influence our nation's course, won a small measure of victory.

\section{An overlooked barrier to civic participation}

Yet today, there looms another less conspicuous barrier to civic inclusion that threatens to undermine the tenets of participatory democracy and active liberty (see Breyer 2005). Felon jury exclusion statutes permeate our nation's landscape at a rate unseen by those who once prevented convicted felons from voting. Thirty-one states and the federal government permanently preclude those with a felony criminal record from serving on juries-civil or criminal (Kalt 2003:65, 67). Seventeen others restrict a felon's ability to serve in less drastic fashion (Kalt 2003:158), while only two states, Colorado and Maine, allow those convicted of a felony to decide the fate of another (Kalt 2003:158).

As the "very palladium of free government" (Hamilton 1961:498), the jury trial is "the central element in the American conception of justice" (Hastie et al. 1983:1). Further, "the tale of the empowered juror illustrates both the Framers' vision of the 
American jury and the reality of the institution today" (Young 2006:67-68). Fundamental to the educative aspects of democracy, jury service prompted Alexis de Tocqueville to note that "[b]y obliging men to turn their attention to other affairs than their own, it rubs off that private selfishness that is the rust of society...I think that the practical intelligence and political good sense of the Americans are mainly attributable to the long use that they have had of the jury" (cited in Adler 1994:4). Still, scholars and policymakers largely overlook the measures that keep convicted felons from serving.

As a practicing attorney, I understand the vital role the jury plays in the American justice system; as a convicted felon, I also understand the civic isolation that my exclusion from that process fosters. Kept from serving because I purportedly "threaten the probity of the jury" (Kalt 2003:73 n.10) and because I am "inherently biased" (Kalt 2003:73-74), I have no access to an experience some have called "transformative" (Haddon 1994:29, 60, noting that "[t]he jury's civic responsibility...extends beyond its principal duty of resolving the dispute for individuals in particular case"). Like those legal constructs that permanently banish felons from casting a ballot, the statutes that categorically deny felons the right to sit on a jury threaten our democratic ideals.

\section{A most invisible punishment}

Unlike voter disenfranchisement, felon jury exclusion is not a visible sanction. The jury trial is an increasingly rare occurrence (Young 2006:73 n.15, noting that "jury trials are, with surprising rapidity, becoming things of the past"). For example, in the federal court system, civil trials now are "largely the product of summary judgment" (Young 2006, citing Wald 1998) and criminal defendants face sentencing guidelines that call for sentences accompanying a guilty jury verdict that are "five hundred percent longer than sentences received by those who plead guilty and cooperate with the government" (Young 2006, citing Berthoff v. United States 2001). Thus, it is clear that it would be a rarity for an event like the 2000 presidential election to publicly unearth these statutes that marginalize millions of Americans.

Moreover, when a criminal trial does attract widespread media attention, the public is never privy to the jury selection process. Television does not publicize the rather mundane process of voir dire, nor does it spotlight the distribution of jury questionnaires, or the dismissal of certain jurors. No camera captures the state or the federal government dismissing an otherwise eligible juror because of a felony conviction. Instead, the public sees only twelve seated jurors ready to embark on their civic duty.

\section{Justified as necessary}

Many seem to find the rationales behind felon jury exclusion logical, failing to question whether the purported justifications for preclusion are empirically valid. Do all felons really harbor biases against the state? And do all felons really threaten 
the sanctity of the deliberation room? Some argue that felon jury exclusion differs from other collateral sanctions in that the presumptions at work in this legislation somehow justify the exclusion of millions of citizens.

For instance, in his article "Invisible Punishment: An Instrument of Social Exclusion," Jeremy Travis offers several methods by which "to constrain the impulse to punish those who violate our laws by diminishing their rights and privileges" (Travis 2002:35). One recommendation made by Travis is what he calls "individualized justice" (Travis 2002). This normative principle is rather straightforward: states ought to tailor collateral sanctions so that they serve a purpose but are not so overinclusive as to amount to unnecessary punishments that create barriers to readjustment.

Yet, in condemning those sanctions that are overinclusive, Travis offers a rather counterintuitive example of a collateral sanction that "may appropriately be automatic" (Travis 2002). He notes that "barring convicted felons from jury eligibility automatically may well be reasonable to protect the integrity of criminal trials" (Travis 2002). He goes onto argue that "the vast majority of collateral sanctions cannot be justified this way...these sanctions should be imposed in ways that tailor the punishment to the circumstances" (Travis 2002).

While I agree with Travis generally that collateral sanctions necessitate tailoring, I wonder why he views felon jury exclusion differently. Are convicted felons so homogenous and biased that we all are unfit to serve on a jury? How is that different from categorically barring felons from being barbers, or firefighters, or professors? I call on this example because it illustrates the seemingly flawed logic that has infiltrated this form of civic banishment. Many presume that all felons taint a process simply because they have negative experiences associated with that process. But, what if all felons do not view their experiences with the criminal justice system as negative? What if the heroin addict who got clean did so only because the state locked him in a cell and forced him to withdraw without temptation? Would he harbor an inherent bias against the government that saved his life?

One other disturbing inconsistency that plagues assumptions like that proffered by Travis is how courts generally handle trials in which a felon-juror has somehow taken part in the deliberation process. For example, in December 2008, the Michigan Supreme Court ruled to uphold a verdict rendered by a jury that included a felon (People v. Miller 2008). The defendant in the case stood accused of committing the identical crime for which the state had convicted the felon-juror (People v. Miller 2008). Nevertheless, though state law makes statutorily ineligible those with a felon criminal record, the Michigan Supreme Court held that there was no evidence of partiality and that the illicit verdict must stand (People v. Miller 2008).

This case raises two important questions. First, if all felons harbor an inherent bias such that they are adversarial toward the state, as Travis and others assume, why then did that felon-juror convict? And, if the presence of a felon-juror so corrupts the jury process, why did the Michigan Supreme Court uphold the verdict? While the second question requires a rather subjective analysis, the first does not. Felon jury exclusion statutes per se bar felons from the jury process because they allegedly harbor a bias so irreparable that it prevents all felons from rendering a 
decision in line with government assertions. Yet, when a felon does sit on a jury in a criminal case and renders a guilty verdict, that overinclusive presumption fails logically. Addressing Travis, in that instance, barring convicted felons from jury eligibility automatically is not reasonable to protect the integrity of criminal trials. Instead, an individualized assessment of juror fitness is proper. All states ought to allow convicted felons to take part in voir dire, as they do many other groups that likely harbor biases equally as strong as those allegedly held by convicted felons (i.e., crime victims, law enforcement personnel, corrections officials, etc.). Such a development would promote inclusion and facilitate civic participation.

\section{Does it really matter?}

Some argue that jury service is a burden, a task few eagerly anticipate. Law professor Brian C. Kalt questions "whether excluding a person from jury service is really a penalty, or if instead it is actually something of a reward" (Kalt 2003:118 n.10). But this is a privileged perspective. For those of us whom the state exiles, felon jury exclusion represents a $\operatorname{cog}$ in a machine that establishes convicted felons as "outsiders" (see Becker 1963) marked as such and treated accordingly.

Though my experiences may differ significantly from others who live with the mark of a felonious criminal history, I suspect that if asked, many of my unfortunate brethren would profess a desire to serve as a juror. When the state released me, I had lost years of my life and countless rights associated with being an American citizen. I knew I was different, and many reminded me of this daily. My desire to sit on a jury, to vote, to run for office, and to partake in many other forms of social life from which I am now barred, stems from a need to feel equal to those with whom I share my existence. In sum, I just seek meaningful forgiveness.

I do not profess to believe that solely allowing convicted felons to participate in the jury process will lower recidivism rates or foster a sense of belonging for those living with a criminal record. Yet, I do contend that the elimination of felon jury exclusion is a step toward mediating a larger framework of stigmatization and marginalization. Legal restrictions that dictate who can and cannot take part in democratic institutions create the core of the marginalization so often illuminated by those who study reentry and its effects. But, felon jury exclusion remains in the shadows, garnering support from unlikely advocates and continuing to plague the existence of millions of quasi-citizens walking the streets of this nation.

Open Access This article is distributed under the terms of the Creative Commons Attribution Noncommercial License which permits any noncommercial use, distribution, and reproduction in any medium, provided the original author(s) and source are credited.

\section{References}

Adler, Stephen J. 1994. The Jury: Disorder in the Court. New York: Doubleday \& Company, Inc. American Bar Association. 2003. Standards on collateral sanctions and discretionary disqualification of convicted persons. 
Becker, Howard S. 1963. Outsiders: Studies in the Sociology of Deviance. New York: Free Press.

Breyer, Stephen. 2005. Active Liberty: Interpreting Our Democratic Constitution. New York: Vintage. Haddon, Phoebe A. 1994. Rethinking the Jury. William and Mary Bill of Rights Journal 3: 29-106.

Hamilton, Alexander. [1787] 1961. The Federalist No. 83. In The Federalist Papers, ed. Clinton Rossiter. Seattle: Mentor.

Hastie, Reid, Steven D. Penrod, and Nancy Pennington. 1983. Inside the Jury. Clark, NJ: The Lawbook Exchange, Ltd.

Kalt, Brian C. 2003. The Exclusion of Felons from Jury Service. American University Law Review 53: 65-189.

Lincoln, Abraham. 1863. Address at Gettysburg http://showcase.netins.net/web/creative/lincoln/speeches/ gettysburg.htm Accessed 29 January 2010.

Manza, Jeff, and Christopher Uggen. 2006. Locked Out: Felon Disenfranchisement and American Democracy. New York: Oxford University Press.

People v. Miller. 2008. 482 Mich. 540.

Putnam, Robert. 2000. Bowling Alone: The Collapse and Revival of American Community. New York: Simon \& Schuster.

Travis, Jeremy. 2002. Invisible Punishment: An Instrument of Social Exclusion. In Invisible Punishment: The Collateral Consequences of Mass Imprisonment, ed. Marc Mauer and Meda Chesney-Lind. New York: New Press.

Young, Hon. William G. 2006. Vanishing trials, vanishing juries, vanishing constitution. Suffolk University Law Review 40: 67. 